\title{
The nursing process in postpartum consultations at Primary Health Care Units*
}

\author{
O processo de enfermagem nas consultas de puerpério \\ em unidades de Atenção Primária em Saúde \\ El proceso de enfermería en las consultas de puerperio en \\ las unidades de Atención Primaria de Salud
}

How to cite this article:

Garcia NP, Lettiere-Viana A, Santos F, Matumoto S, Kawata LS, Freitas KD. The nursing process in postpartum consultations at Primary Health Care Units. Rev Esc Enferm USP. 2021;55:e03717. doi: https://doi.org/10.1590/S1980-220X2020005103717

\section{D) Nayara Paes Garcia ${ }^{1}$ \\ Angelina Lettiere Viana ${ }^{1}$ \\ Fernanda Santos ${ }^{1}$ \\ Silvia Matumoto ${ }^{1}$ \\ Lauren Suemi Kawata ${ }^{2}$ \\ Karina Domingues de Freitas ${ }^{2}$}

* Extracted from the undergraduate research: "Análise do processo de enfermagem em consultas de puerpério em unidades de atenção básica”, Escola de Enfermagem de Ribeirão Preto, Universidade de São Paulo, 2019.

1 Universidade de São Paulo, Escola de Enfermagem de Ribeirão Preto,

Departamento Materno-Infantil e Saúde Pública, Ribeirão Preto, SP, Brazil.

2 Secretaria Municipal de Saúde de

Ribeirão Preto, Divisão de Enfermagem,

Ribeirão Preto, SP, Brazil.

\begin{abstract}
Objective: To identify the steps of the Nursing Process and integral care. Method: Document analysis study on medical and nursing consultations records during postpartum conducted in primary health units in inland São Paulo state. The analysis comprised the registered steps, the sequence of steps, and the approach of psychosocial questions. The data are presented by frequency, percentage, and the expressed content of care. Results: The analyzed records amounted to 341 . Out of these, $100 \%$ presented History; 62.2\%, Nursing Diagnosis; 5.3\%, Planning; 99.1\%, Implementation; and 50.1\%, Evaluation. Regarding the sequence of steps, $47.5 \%$ of the medical records presented three steps. In the incorporation of the principle of integrality, a more frequent presence of the biological approach was observed. Conclusion: This study shows the change of practice of nurses, with efforts to register the Nursing Process, and that the integrality of care constitutes a challenge to surpass a model of care which is fragmented and decontextualized from the life conditions of people.
\end{abstract}

\section{DESCRIPTORS}

Primary Care Nursing; Postpartum Period; Nursing Process; Maternal-Child Nursing.
Corresponding author:

Angelina Lettiere Viana

Av. dos Bandeirantes, 3900

Campus Universitário - Bairro Monte Alegre CEP 14040-902 - Ribeirão Preto, SP, Brazil angelina.lettiere@usp.br
Received: 02/12/2020 Approved: 09/30/2020 


\section{INTRODUCTION}

In Brazil, the nurse is part of the multiprofessional team and stands out as a key professional in strengthening the Primary Health Care (PHC) and the Unified Health System (Sistema Único de Saúde - SUS) ${ }^{(1)}$. In addition, the work in nursing is an instrument of change in healthcare practices, which responds to a new care model. Its actions promote broadening the limits of professional practice to accomplish integral care of people, families, and communities ${ }^{(2)}$.

The nursing work in the team encompasses a range of inter-related activities with common actions and actions exclusive to the nurse regarding care and management. The developed activities are multifaceted, such as individual and collective care, domiciliary visits, health education, meeting spontaneous demands, permanent education of the health team, assessment of activities of community workers, among other actions ${ }^{(3)}$. In individual care, the Nursing Consultation (NC) is emphasized. It is considered a space for care with potential to broaden access and problem-solving in $\mathrm{PHC}^{(4)}$. This is also the main setting for the development of clinical practice, with systematized actions which contribute to quality of care through evidence-based practice ${ }^{(5)}$.

In $\mathrm{NC}$, one of the systematized actions is the Nursing Process (NP), characterized by the Brazilian Federal Nursing Council in Resolution n. 358/2009 as a methodological instrument which orients care and the documentation of the professional activity. The NP is organized into five inter-related, interdependent, and recurrent steps, which are: History, Nursing Diagnosis, Nursing Planning, Implementation, and Nursing Evaluation ${ }^{(6)}$. Thus, the NP demands from the nurse cognitive, psychomotor, and affective skills and capabilities, which require critical judgment, flexibility, and creativity for building shared care plans considering people's health needs. In PHC, implementing the NP and registering it appropriately is still a challenge, which impacts the way of providing evidence for the quality of nursing actions within the nurse's clinical practice ${ }^{(7)}$.

In the context of $\mathrm{NC}$, the postpartum consultations are emphasized, given that this period denotes expressive morbidity and mortality for women ${ }^{(8)}$ and that the $\mathrm{NC}$, through $\mathrm{NP}$, may be an important moment for the promotion of women and family health ${ }^{(9)}$. The PHC is the main setting for care and follow-up of women in this period, given the amplitude of actions supported by soft technology which favor the early detection of physical, psycho-emotional, and social changes, which may have an impact on the reduction of maternal mortality and morbidity ${ }^{(8)}$.

This study approaches the NP in the NC directed at puerperal women and is justified by the need to explore more deeply its use in PHC, considering that the implementation of this instrument that qualifies nursing care practice is still constituted as a problem ${ }^{(7)}$. Also, Brazilian studies on the theme of postpartum are limited to exploring the number of consultations, the number of domiciliary visits, the impact of breastfeeding programs, among other themes ${ }^{(8)}$; there are no studies on the NP in NC during the postpartum period in $\mathrm{PHC}$ contexts ${ }^{(8-11)}$.
The social relevance of this study is also emphasized, since it corroborates the practice of university extension (university-education-work), given the necessity posed by the context of the municipality participating in this study, aimed at improving practices which involve both nursing care and qualification of professionals working at $\mathrm{PHC}$ units. Thus, the objective of this study was to identify the steps of the Nursing Process and integral care, i.e., identifying which steps of the NP were registered and to verify whether they contemplated the perspective of integral care.

\section{METHOD}

\section{Design OF STUdY}

This a descriptive, document analysis study, whose documents were not submitted to any type of scientific treatment ${ }^{(12)}$.

\section{LOCATION}

The data were collected from the electronic medical records of $\mathrm{NC}$ in the postpartum period conducted at Basic Health Units (BHU) and Family Health Units (FHU) of a large-sized municipality in inland São Paulo state. This health network is organized into five Health Districts (North, South, East, West, and Center), which have five Basic District Health Units (BDHU), 26 BHU and 18 FHU. Since 2008 the health units employ a Public Health Management System, named HygiaWeb, which provides for registering health service users online and includes the register of $\mathrm{NC}$, in addition to many other functions. Out of $49 \mathrm{BHC}$ units, 42 employ electronic medical records and were the location for this study.

\section{SAMPLE DEFINITION}

Sample selection comprised the year 2017, given that this research started in 2018; in this year, the HygiaWeb system has been through changes in the fields for NC register and, for this reason, nurses were being trained. In 2017, in the health units, 3,011 NC were conducted in the postpartum period, with which sampling for collection, analysis, and data interpretation were performed. Random Stratified Sampling was adopted for sample calculation, with proportional allocation per stratum (five districts). The prevalence taken as the basis for calculation was unknown ${ }^{(13)}$ and a conservative estimate was adopted for sample size, with a prevalence value of $50 \%$. Thus, by adopting the parameters of relative error of $10 \%$, significance level of $5 \%$, and prevalence of $50 \%$ in each stratum, the sample sizes were 05 medical records in the Central District, 41 medical records in the East District, 117 medical records in the North District, 101 medical records in the West District, and 77 medical records in the South District, amounting to a total 341 medical records. The medical records were randomly selected by the registration number of the puerperal women. The program adopted for sample calculation and for randomly selecting medical records was $R$ ( $R$ Core Team) version 3.1.2. 
The medical records with registers of NC during the postpartum period in 2017 were included.

\section{Data collection}

The authors elaborated an instrument for data collection referring to the characterization of pregnancy and postpartum and the health district, reserving a field for integral copy of the text of NP steps. The data were collected from January to March 2019 in a computer in the headquarters of the Municipal Health Office, with online consultation to the medical records and copy of the NC annotation. The researchers were trained to manage the HygiaWeb system and two of them performed the data collection, completing the instrument with double typing into a database. An integral copy of the text was made, since, during the research, the electronic medical records did not present a specific area for each NP step, which was noticed in the pre- consultation, consultation, and post-consultation fields.

\section{Data TREATMENT AND ANALYSIS}

In data analysis, aspects considered important for NC during the postpartum period were explored, such as data of pregnancy and postpartum. Regarding the NP, aspects such as the registered steps, the sequence of register of the steps which are presented in frequency and percentage, and, finally, the contents of psychosocial issues which comprise the concept of integrality of care were examined ${ }^{(14)}$.

\section{ETHICAL ASPECTS}

This research meets the ethical recommendations of Resolution 466/12 by the National Health Council and was approved by the Municipal Health Office and by the Research Ethics Committee of Escola de Enfermagem de Ribeirão Preto, in CEP-EERP-USP Letter n. 203/2018. Since this is a document research on electronic medical records and with no contact with users or nurses, informed consent was waived.

\section{RESULTS}

The analyzed medical records referring to postpartum $\mathrm{NC}$ amounted to 341. Regarding the age of the puerperal women, the analysis by stratum showed that $14.7 \%$ were younger than $19 ; 52.2 \%$, were between 20 and 29 years old; $29.2 \%$ were between 30 and 39 years old; and 3.9\%, were above 40 . The mean of pregnancies ranged from 1.8 to 2.5 , with a minimum of 1 and a maximum of 8 pregnancies. The mean of births was 1.8 to 2.3 , with a minimum of 1 and a maximum of 6 births. Finally, the number of abortions varied from none to four.

The number of prenatal consultations was analyzed, and the following distribution was obtained: North District $(n=117)$, with a mean of 9.1 consultations (min. 4 and max. 14) and $50.4 \%$ of medical records with no information. In the South District ( $n=77)$, the mean was 9.7 consultations (min. 3 and max. 15) and 70.1\% of medical records with no information. In the East District $(n=41)$, the mean was 9.0 consultations (min. 4 and max. 12) and $73.1 \%$ of medical records with no information. In the West District $(n=101)$, the mean was 8.9 consultations (min. 4 and max. 14) and $74.2 \%$ of medical records with no information. In the Center District $(n=5)$, the randomly chosen medical records had no information on the number of prenatal consultations. As for the gestational age of delivery, there was a mean 38.4 weeks of pregnancy. The information of number of postpartum days in the NC was present in 258 (75.6\%) of the medical records, whereas it was absent in 83 (24.4\%). The consultations were conducted from the 4 th to the 5 th day postpartum, with, respectively, 70 (27.1\%) and $63(24.4 \%)$ medical records. The data related to pregnancy and postpartum are presented in Table 1. Such data refer to the medical records which had the respective information.

Table 1 - Data referring to pregnancy and postpartum registered in the electronic medical records of postpartum consultations Ribeirão Preto, SP, Brazil, 2019.

\begin{tabular}{|c|c|c|}
\hline \multirow{2}{*}{ History } & \multicolumn{2}{|c|}{ Medical records $(n=341)$} \\
\hline & Freq. & $\%$ \\
\hline Number of pregnancies & 215 & 63.1 \\
\hline Primigravidae & 73 & 34.0 \\
\hline Gravida 2 & 73 & 34.0 \\
\hline Gravida 3 & 38 & 17.6 \\
\hline Gravida $\geq 4$ & 31 & 14.4 \\
\hline Parity & 217 & 63.6 \\
\hline Primiparous & 82 & 37.7 \\
\hline Multiparous & 135 & 62.3 \\
\hline Abortion & 207 & 60.7 \\
\hline None & 173 & 83.6 \\
\hline One & 26 & 12.5 \\
\hline Two or more & 12 & 3.9 \\
\hline Pregnancy & 303 & 88.8 \\
\hline Unplanned & 300 & 99 \\
\hline Planned & 03 & 1.0 \\
\hline Prenatal & 112 & 32.8 \\
\hline Unified Health System & 93 & 83.1 \\
\hline Health plan & 18 & 16.1 \\
\hline Did not perform & 01 & 0.8 \\
\hline Type of birth & 324 & 95.1 \\
\hline Normal & 208 & 64.2 \\
\hline Cesarean section & 116 & 35.8 \\
\hline $\begin{array}{l}\text { Companion in the postpartum } \\
\text { consultation }\end{array}$ & 82 & 24.5 \\
\hline Unaccompanied & 26 & 31.8 \\
\hline Husband & 45 & 54.8 \\
\hline Relatives & 11 & 13.4 \\
\hline Breastfeeding & 153 & 44.8 \\
\hline Exclusive breastfeeding on demand & 133 & 86.9 \\
\hline Mixed breastfeeding & 18 & 11.8 \\
\hline Artificial feeding & 02 & 1.3 \\
\hline
\end{tabular}


Regarding the presence of the NP steps, all the 341 (100\%) medical records were verified to have the History step; 212 (62.2\%), the Nursing Diagnosis step; 18 (5.3\%), the Planning step; 338 (99.1\%), the Implementation step; and 171 (50.1\%), the Evaluation step. Table 2 shows the distribution of the registers of each step of the NP in the five health districts.

Table 2 - Register of the Nursing Process steps in electronic medical records of postpartum consultations - Ribeirão Preto, SP, Brazil, 2019.

\begin{tabular}{|c|c|c|c|c|c|c|c|c|c|c|}
\hline \multirow{2}{*}{ Districts } & \multicolumn{2}{|c|}{ History $(n=341)$} & \multicolumn{2}{|c|}{ Diagnosis $(n=341)$} & \multicolumn{2}{|c|}{ Planning $(n=341)$} & \multicolumn{2}{|c|}{ Implementation $(n=341)$} & \multicolumn{2}{|c|}{ Evaluation $(n=341)$} \\
\hline & Freq. & $\%$ & Freq. & $\%$ & Freq. & $\%$ & Freq. & $\%$ & Freq. & $\%$ \\
\hline North $(n=117)$ & 117 & 100.0 & 110 & 94.0 & 15 & 12.8 & 115 & 98.3 & 82.0 & 70.1 \\
\hline South $(n=77)$ & 77 & 100.0 & 21 & 27.3 & - & - & 77 & 100.0 & 66.0 & 85.7 \\
\hline East $(n=41)$ & 41 & 100.0 & 26 & 63.4 & - & - & 40 & 97.6 & 16.0 & 39.0 \\
\hline West $(n=101)$ & 101 & 100.0 & 50 & 49.5 & 03 & 3.0 & 101 & 100.0 & 7.0 & 6.9 \\
\hline Center $(n=5)$ & 05 & 100.0 & 05 & 100.0 & - & - & 05 & 100.0 & - & - \\
\hline Total $(n=341)$ & 341 & 100.0 & 212 & 62.2 & 18 & 5.3 & 338 & 99.1 & 171.0 & 50.1 \\
\hline
\end{tabular}

Also, regarding the NP steps, the order registered in the medical records was also surveyed. Thus, out of 341 medical records, 12 (3.5\%) were observed to contain five NP steps, 100 (29.4\%) medical records registered four NP steps; in 162
(47.5\%) there were three NP steps and, finally, 67 (19.6\%) medical records presented two NP steps. The distribution by Districts is found in Table 3.

Table 3 - Frequency of registers of the steps of the Nursing Process in electronic medical records of postpartum consultations - Ribeirão Preto, SP, Brazil, 2019.

\begin{tabular}{|c|c|c|c|c|c|c|c|}
\hline \multirow{2}{*}{ Districts } & \multirow{2}{*}{$\begin{array}{c}\text { Five Steps }(\mathrm{n}=12) \\
\text { H/ND/P/I/E }\end{array}$} & \multicolumn{2}{|c|}{$\begin{array}{c}\text { Four Steps } \\
(\mathbf{n}=\mathbf{1 0 0})\end{array}$} & \multicolumn{2}{|c|}{$\begin{array}{l}\text { Three Steps } \\
(\mathbf{n = 1 6 2 )}\end{array}$} & \multicolumn{2}{|c|}{$\begin{array}{c}\text { Two Steps } \\
(\mathrm{n}=67)\end{array}$} \\
\hline & & $\mathrm{H} / \mathrm{ND} / \mathrm{P} / \mathrm{I}$ & H/ND/I/E & H/ND/I & $\mathrm{H} / \mathrm{I} / \mathrm{E}$ & H/ND & $\mathrm{H} / \mathrm{I}$ \\
\hline North $(n=117)$ & 12 & 03 & 68 & 25 & 02 & 02 & 05 \\
\hline South $(n=77)$ & - & - & 16 & 05 & 50 & - & 06 \\
\hline East $(n=41)$ & - & - & 05 & 20 & 11 & 01 & 04 \\
\hline West (n=101) & - & 03 & 05 & 42 & 02 & - & 49 \\
\hline Center $(n=5)$ & - & - & - & 05 & - & - & - \\
\hline Total $(n=341)$ & 12 & 06 & 94 & 97 & 65 & 03 & 64 \\
\hline
\end{tabular}

In the evaluation of the incorporation of the principle of integrality in the NP registers, the contents of the registers were searched for topics related to the health biopsychosocial needs of puerperal women. Chart 1 shows a higher presence of the biological approach, with few registers approaching psychosocial aspects.

Chart 1 - Synthesis of the contents of the registers in the steps of the Nursing Process in electronic medical records of postpartum consultations - Ribeirão Preto, SP, Brazil, 2019.

\begin{tabular}{|l|l|}
\hline NP steps & Most frequent contents in the registers \\
\hline \multirow{5}{*}{ History } & $\begin{array}{l}\text { Biological Aspects: Weight, height, body mass index, blood pressure, capillary glycemia, delivery, vaccine status, } \\
\text { serology, blood typing, pregnancies, deliveries, abortions, number of prenatal consultations, gestational age and age } \\
\text { of the puerperal woman, postpartum days, pathologies, pregnancy complications, presence of sexually transmitted } \\
\text { infections, physical exam of breast and body, nutritional habits, use of drugs of abuse, use of medication, breastfeeding, } \\
\text { newborn care, type of feeding, and use of contraceptive methods. }\end{array}$ \\
\cline { 2 - 3 } Diagnosis & $\begin{array}{l}\text { Psychosocial aspects: Planned pregnancy, family support, companion, psychoemotional aspects, vulnerability, risk of } \\
\text { domestic violence, mother-child bond, and profession. }\end{array}$ \\
\hline & $\begin{array}{l}\text { Biological aspects: Appropriate breastfeeding, intact mammary gland, appropriate body hygiene, appropriate vaccine } \\
\text { status, excoriated nipples, postpartum with no changes so far, pregnancy prevention, postpartum signs/symptoms, } \\
\text { nipple fissure, preventive medicine/health maintenance, nipple with no solution of skin integrity, birth with no } \\
\text { complications for born alive infant, normal birth postpartum, risk of perineal infection, risk of mastitis, difficulties in } \\
\text { maternal breastfeeding, breast pain due to milk letdown, inappropriate sleep, altered rest. }\end{array}$ \\
\cline { 2 - 2 } & \begin{tabular}{l} 
Psychosocial aspects: Mother-child bond preserved. \\
\hline
\end{tabular} \\
\hline
\end{tabular}




\begin{tabular}{|l|l|}
\hline N...continuation & Most frequent contents in the registers \\
\hline \multirow{5}{*}{ Planning } & $\begin{array}{l}\text { Biological Aspects: Stimulating breastfeeding up to the age of } 6 \text { months; orientating on nourishment, breast care, } \\
\text { breastfeeding, contraceptive methods, and signs of breast with complications, confinement, care of their own bodies, } \\
\text { care of newborn. }\end{array}$ \\
\cline { 2 - 3 } & $\begin{array}{l}\text { Psychosocial aspects: Stimulate the mother-child bond, orienting labor rights and maternity leave, evaluate the risk of } \\
\text { family violence, verify family support. }\end{array}$ \\
\hline \multirow{5}{*}{ Implementation } & $\begin{array}{l}\text { Biological aspects: Orientation on nourishment, care towards the newborn, breast care, puerperal woman's body } \\
\text { hygiene, breastfeeding on demand, importance of the exclusive breastfeeding up to six months of age, use of } \\
\text { contraceptive methods, confinement, use of condom for prevention of sexually transmitted infections, consultation } \\
\text { scheduling. }\end{array}$ \\
\cline { 2 - 3 } Evaluation & $\begin{array}{l}\text { Psychosocial aspects: Mother-child bond stimulus; orientation on labor rights and maternity leave; risk of family } \\
\text { violence evaluated; family support verified. }\end{array}$ \\
\hline Biological aspects: Evaluation of the breasts and breastfeeding, evaluation of vaccine status, newborn weight gain. \\
\cline { 2 - 3 } & $\begin{array}{l}\text { Psychosocial aspects: Positive bond between mother and newborn, risk of family violence, appropriate comprehension, } \\
\text { and participation in the offered orientations. }\end{array}$ \\
\hline
\end{tabular}

Source: Elaborated from the registers of electronic medical records of postpartum consultations- Ribeirão Preto, SP, Brazil, 2019.

\section{DISCUSSION}

The NP may be conceived of as an intellectual tool for the nurse's work which may stimulate clinical and investigative thinking, fostering decision-making and the construction of a new body of knowledge of this profession. Its use reflects the nurses' commitment with the users under their care in the promotion of appropriate care to satisfy the health needs of users, family, and community ${ }^{(15)}$. The NP must be conducted in an intentional and systematic way in five steps: History, Nursing Diagnosis, Planning, Implementation, and Evaluation ${ }^{(6)}$.

The History step is characterized as the moment when the nurse conducts anamnesis and the physical exam and obtains information on the person to evaluate its health status and/or confirm possible problems or needs ${ }^{(6)}$. This step was identified in all the analyzed medical records and it may thus be inferred that performing this step might be a routine practice by the nurses, since they rely on this information to conduct care activities. A qualitative study with FHU nurses has also identified that this step was the only one that all interviewees reported performing ${ }^{(16)}$. Differently, a quantitative study ${ }^{(17)}$ with 416 nurses who work in public institutions (hospitals, clinics, and outpatient facilities) administered by the São Paulo State Health Office, has identified that the step for raising data was one of the least documented NP steps (78.8\%). These studies do not approach the theme of postpartum, but other aspects of nursing care.

The registers of the history are emphasized not to be standardized regarding the information collected during anamnesis, since the data referring to pregnancy, delivery, postpartum, and others considered as fundamental for the postpartum care plan were not present in all records. The use of a validated instrument is thus recommended, as this may contribute to systematic postpartum care and promote the operationalization of the NP in the context of $\mathrm{PHC}^{(11)}$.

The Nursing Diagnosis enables the professional to identify, determine, and name the health problems or needs of individuals, families, or communities from information obtained during data collection, using diagnostic rationale, scientific knowledge, and clinical experience ${ }^{(6)}$. This step was present in $62.2 \%$ of medical records. A quantitative study conducted in a PHC unit in inland São Paulo state has identified that some steps are not conducted systematically and, in relation to the diagnosis, in the nurses' perception, 50\% of nurses were shown to conduct the diagnosis sometimes; $25 \%$, rarely; and $25 \%$, many times ${ }^{(18)}$. The literature points out that the difficulty in conducting the diagnosis is due to lack of knowledge or little acquaintance of the professionals with the diagnosis classification systems ${ }^{(16,18)}$. However, for this study's setting, a deeper investigation with the professionals is required.

From the NP steps, Planning is emphasized as the least present in the registers, identified in only $5.3 \%$ of the medical records. From the prioritization of the Nursing Diagnosis given the user's health needs -, the nurses employ their technical-scientific knowledge to establish the results and goals for each situation, planning and prescribing nursing action which should be put into practice to achieve the results ${ }^{(6)}$. The fact that this step is the least documented does not entail that nurses do not perform it, since the Implementation step was the second most identified one (99.1\%). The implementation refers to the execution by professionals of the prescribed actions to obtain improvements in promotion, prevention, and health recovery of users ${ }^{(6)}$.

Such inference is shown by the misuse, in registers, of verbs characterizing the steps Planning and Implementation, which shows the professionals' difficulty in distinguishing these two steps. Thus, the reasons for the gap between these two steps may be related to an incomprehension of central concepts in each NP step ${ }^{(19)}$. A nation-wide Brazilian study with nurses has identified that these professionals wish to learn more about the NP, mainly about the Planning step ${ }^{(20)}$, which reinforces the inference on the difficulty in this step.

The step of Evaluation identifies changes in the health status or user behavior considering the care provided in the Implementation step, i.e., the goals and results established in the Planning step are checked for whether they have been achieved, characterizing the evolution of nursing, i.e., the evaluation of provided care and the results achieved in a pre-established period $^{(6)}$. This step was identified in $50.1 \%$ of the analyzed medical records. 
Although not in a PHC setting, a study conducted in a hospital to evaluate the perception of 141 nursing regarding the NP concluded that they understand moderately (66\%) the conduction of nursing evaluation ${ }^{(21)}$. However, this is believed not to be the main reason for this step being present in half of the medical records. When considering the context of PHC and the principle of longitudinality to evaluate care provided in a certain period, the user would supposedly need to return home and only when returning to the unit or receiving a domiciliary visit for care continuity there would be a timely moment for conducting the evaluation, in which a new register would be performed. In this study, however, only the first consultation was evaluated. Thus, to better understand and clarify this issue, an investigation that considered care throughout this period would be required.

In relation to the sequence of steps of the NP, different steps were documented, with a variation from two to five steps. A study has shown that the number of documented steps varies according to the context of production of care. The sectors which provide care to hospitalized users, such as intensive treatment units, general nursing ward, obstetric center, and day hospital, have presented the five registered steps. Sectors receiving non-hospitalized patients, such as the diagnosis support service (two steps), outpatient facilities and emergency services (three steps), were the ones documenting the smallest number of steps. Also, the NP steps were not systematically documented ${ }^{(17)}$. It is thus important to consider the local where care production takes place, since these contexts may influence the reasons for the absence or incompleteness of an NP register. Also, the conduction of studies to help deepen the comprehension of this phenomenon in PHC would be valid.

Given the importance of such information, an unstructured register may compromise the quality of care provided by nurses and by the institution, as well as impair communication among the team members, given the importance of registers as the main form of documentation of professional practice ${ }^{(6)}$. This situation may negatively impact service provision, since an unstructured register hinders individualization, integrality, and continuity of care ${ }^{(22-23)}$.

Studies show that the NP is often not developed in all its steps due to factors such as lack of training, NC interruptions, lack of institutional support, work overload of nurses, routine with tasks performed mechanically, devaluation of nurses by the population, precarious physical space and materials, and disregard for the NP by the multiprofessional team. Another point emphasized by the literature is the lack of or insufficient training for NP during undergraduate education, mainly for professionals who have graduated a longer time ago, which might have had no contact with NP, leading to difficulties in using it in their professional practice ${ }^{(18,24-26)}$. This study is emphasized not to have evaluated this dimension, but raising these points is pertinent to reaffirm that these issues are present throughout the production of care and that this context must be considered in the elaboration of policies and actions to favor changes in practice for the implementation of the NP.
In the evaluation of the incorporation of the principle of integrality of care into the $\mathrm{NC}$ in the postpartum period, the results of this study show that the topics related to biopsychosocial health needs are present in a smaller amount, with a higher number of registers contemplating a biological approach. In the biological aspects, a focus on returning the woman's body to pre-pregnancy conditions, preventing postpartum complications, breastfeeding, and newborn health promotion is observed. The medical records reporting psychosocial information are focused on aspects of vulnerability and risk, such as family violence, labor rights, and family support, which identifies the context in which a person is inserted and the social determination of the health-disease process. A study which sought to understand the perceptions of welcoming practices in postpartum care identified that care, in the postpartum consultation, is not constituted as a welcoming space for women's psychosocial needs ${ }^{(27)}$.

The postpartum period is a moment in which the woman takes new roles in society and, to develop integral care, it is fundamental for health professionals to acknowledge their needs ${ }^{(10)}$. For such, integral care must be understood as a teamwork which includes the task of comprehending that woman, a mother, in her postpartum period, a worker, and a user of the health service as a historical, social, and political subject. Although health professionals recognize the importance of integral care, its actions are still not articulated to practice, mainly in situations in which the biological aspect stands out more than the other aspects ${ }^{(28)}$. Integral care is thus a challenge to nursing and an important tool to break with the biological paradigm and rebuild health practices, strengthening the welcoming practices of the extended clinic, with interdisciplinary and integrated actions in the care network ${ }^{(14)}$.

This study's results show how the NP is registered in the $\mathrm{NC}$ during the postpartum in the context of PHC. However, these results do not represent the entirety of the reality of this municipality and does not enable the comprehension of to what extent the documented contents reflect the care offered to women. However, this identification enables raising questions to search for ways of improving NP registers. Thus, the importance of promoting actions to favor the conduction of the NP in the PHC is ratified, given its relevance for clinical practice. To this end, policies and actions must focus on the improvement of the work environment and the nurses' knowledge, competences, and practices ${ }^{(19)}$. The limitations of this study are related to its use of a single source for data collection, which restricts its outlook on the phenomenon. Also, the HygiaWeb system did not provide for the registration of information in specific fields for each NP step, which may have limited its execution by nurses and influenced the obtained results. For this reason, it is important to understand the dimension of subjectivity in the nursing work and its influence on the work process, which may contribute to the reasons why the different NP steps are not implemented in the diverse contexts of the nursing profession, given that its manifestation may be implied in the desire of transforming reality ${ }^{(15)}$. 
The HygiaWeb system has been through updates and fields for each NP step are currently implemented for the electronic medical records. This study was innovative for the municipality, since it provided for an analysis of how the NP was conducted, which may be helpful when comparing it to the new system. The nurses were shown to have made efforts to register the NP and, considering this, these professionals should be recognized as pioneers in proposing systematized nursing care, given that the NP is still a challenge in the Brazilian context and in PHC. Integral care constitutes yet another challenge which requires nursing to maintain its efforts to overcome a model of care which is decontextualized from people's conditions. This study has thus shown a process of change in nursing practice with the incorporation of clinical practices and the NP. This change demands continuous efforts and, among them, analyses, such as the one conducted in this study to subsidize adjustments and directions to the local reality.

\section{CONCLUSION}

Regarding the NP steps, the History step is concluded to have been the most frequently registered, whereas Planning was the least frequent. Most medical records presented three NP steps and a dominating presence of the biological approach was observed. These results indicate the importance of this theme and the need for more studies, with distinct methodologies, to identify the difficulties that nurses face when using NP and incorporating the integrality of care into the postpartum consultations in PHC.

\section{RESUMO}

Objetivo: Identificar as etapas do Processo de Enfermagem e o cuidado integral. Método: Estudo de análise documental em prontuários de consultas de enfermagem no puerpério realizadas em unidades da atenção primária no interior do estado de São Paulo. Analisaramse quais etapas foram registradas, a sequência das etapas e a abordagem das questões psicossociais. Os dados estão apresentados em frequência, porcentagem e o conteúdo expresso do cuidado. Resultados: Foram analisados 341 prontuários. Destes, 100\% apresentaram Histórico; 62,2\%, Diagnóstico de Enfermagem; 5,3\%, Planejamento; 99,1\%, Implementação; e 50,1\%, Avaliação. Quanto à sequência das etapas, $47,5 \%$ dos prontuários apresentaram três etapas. Na incorporação do princípio da integralidade, observou-se uma maior presença da abordagem biologicista. Conclusão: Este estudo evidencia a mudança da prática do enfermeiro, com esforços para realizar o registro do Processo de Enfermagem, e que a integralidade do cuidado se constitui como um desafio para ultrapassar o cuidado fragmentado e descontextualizado das condições de vida das pessoas.

\section{DESCRITORES}

Enfermagem de Atenção Primária; Período Pós-Parto; Processo de Enfermagem; Enfermagem Materno-Infantil.

\section{RESUMEN}

Objetivo: Identificar las etapas del Proceso de Enfermería y el cuidado integral. Método: Análisis documental sobre los prontuarios de consultas de enfermería durante el puerperio realizadas en unidades de atención primaria en el interior del estado de São Paulo. Se analizó qué etapas se registraron, la secuencia de las etapas y el abordaje de las cuestiones psicosociales. Los datos se presentan en frecuencia, porcentaje y el contenido del cuidado reportado. Resultados: Se analizaron 341 prontuarios. De ellos, el 100\% presentó Historia; el 62,2\%, Diagnóstico de Enfermería; el 5,3\%, Planeación; el 99,1\%, Ejecución; y el 50,1\%, Evaluación. En cuanto a la secuencia de las etapas el 47,5\% de los prontuarios presentaron tres etapas. En la incorporación del principio de integralidad, se observó una mayor presencia del enfoque biológico. Conclusión: Este estudio evidencia el cambio en la práctica del enfermero, con esfuerzos para realizar el registro del Proceso de Enfermería, y que la integralidad del cuidado se constituye como un desafío para superar el cuidado fragmentado y descontextualizado de las condiciones de vida de las personas.

\section{DESCRIPTORES}

Enfermería de Atención Primaria; Periodo Posparto; Proceso de Enfermería; Enfermería Maternoinantil.

\section{REFERENCES}

1. Halcomb E, Stephens M, Bryce J, Foley E, Ashley C. Nursing competency standards in primary health care: an integrative review. J Clin Nurs. 2016;25(9-10):1193-205. doi: https://doi.org/10.1111/jocn.13224

2. Ferreira SRS, Périco LAD, Dias VRFG. The complexity of the work of nurses in Primary Health Care. Rev Bras Enferm. 2018;71 Suppl 1:704-9. doi: http://dx.doi.org/10.1590/0034-7167-2017-0471

3. Amaral IT, Abrahão AL. Nursing consultation in Family Health Strategy, increasing the recognition of the distinct forms of action: an integrative review. Rev Pesq Cuid Fundam Online. 2017;9(4):899-906. doi: http://dx.doi.org/10.9789/2175-5361.2017.v9i4.899-906

4. Toso BRGO, Filippon J, Giovanella L. Atuação do enfermeiro na Atenção Primária no Serviço Nacional de Saúde da Inglaterra. Rev Bras Enferm. 2016;69(1):182-91. doi: http://dx.doi.org/10.1590/0034-7167.2016690124i

5. Kahl C, Meirelles BHS, Lanzoni GMM, Koerich C, Cunha KS. Actions and interactions in clinical nursing practice in Primary Health Care. Rev Esc Enferm USP. 2018;52:e03327. doi: http://dx.doi.org/10.1590/s1980-220x2017025503327

6. Conselho Regional de Enfermagem de São Paulo. Processo de enfermagem: guia para a prática [Internet]. São Paulo: COREN-SP; 2015 [citado 2020 jan. 22]. Disponível em: http://www.coren-sp.gov.br/sites/default/files/SAE-web.pdf

7. Garcia TR. Systematization of nursing care: substantive aspect of the professional practice. Esc Anna Nery. 2016;20(1):5-10. doi: http:// dx.doi.org/10.5935/1414-8145.20160001

8. Baratieri T, Natal S. Postpartum program actions in primary health care: an integrative review. Ciênc Saúde Coletiva. 2019;24(11):4227-38. doi: http://dx.doi.org/10.1590/1413-812320182411.28112017

9. Ribeiro DHF, Lunardi VL, Gomes GC, Xavier DM, Chagas MCS. Vivências de cuidado da mulher: a voz das puérperas. Rev Enferm UFPE Online. 2014;8(4):820-6. doi: http://dx.doi.org/10.5205/1981-8963-v8i4a9748p820-826-2014 
10. Dantas SLC, Rodrigues DP, Fialho AVM, Barbosa EMG, Pereira AMM, Mesquita NS. Representações sociais de enfermeiros da atenção primária à saúde sobre cuidado de enfermagem no pós-parto. Cogitare Enferm. 2018;23(3):e53250. doi: http://dx.doi.org/10.5380/ ce.v23i3.53250

11. Mazzo MHSN, Brito RS. Instrumento para consulta de enfermagem à puérpera na atenção básica. Rev Bras Enferm. 2016;69(2):316-25. doi: http://dx.doi.org/10.1590/0034-7167.2016690215।

12. Sá-Silva JR, Almeida CD, Guindani JF. Pesquisa documental: pistas teóricas e metodológicas. Rev Bras Hist Ciênc Soc. 2009;1(1):1-15. Disponível em: https://periodicos.furg.br/rbhcs/article/view/10351

13. Bolfarine H, Bussab WO. Elementos de amostragem. São Paulo: Blucher; 2005.

14. Hino P, Horta ALM, Gamba MA, Taminato M, Fernandes H, Sala DCP. Comprehensiveness in the perspective of public health: pathways for the training of the nurse. Rev Bras Enferm. 2019;72(4):1119-23. doi: http://dx.doi.org/10.1590/0034-7167-2018-0443

15. Figueiredo PP, Lunardi Filho WD, Silveira RS, Fonseca AD. The non-implementation of the nursing process: reflection based on Deleuze's and Guattari's concepts. Texto Contexto Enferm. 2014;23(4):1136-44. doi: http://dx.doi.org/10.1590/0104-07072014001380013

16. Costa AS, Dias RBF, Cerqueira JCO, Peixoto RCBO. O processo de enfermagem na atenção básica de um município de Alagoas, Brasil. Rev Enferm Atenção Saúde. 2018;7(1):143-51. doi: http://dx.doi.org/10.18554/reas.v7i1.2201

17. Azevedo OA, Guedes ES, Araújo SAN, Maia MM, Cruz DALM. Documentation of the nursing process in public health institutions. Rev Esc Enferm USP. 2019;53:e03471. doi: http://dx.doi.org/10.1590/s1980-220x2018003703471

18. Ribeiro GC, Padoveze MC. Nursing Care Systematization in a basic health unit: perception of the nursing team. Rev Esc Enferm USP. 2018;52:e03375. doi: http://dx.doi.org/10.1590/s1980-220x2017028803375

19. Akhu-Zaheya A, Al-Maaitah R, Hani SB. Quality of nursing documentation: paper-based health records versus electronic-based health records. J Clin Nurs. 2018;27:e578-89. doi: http://dx.doi.org/10.1111/jocn.14097

20. Oliveira MR, Almeida PC, Moreira TMM, Torres RAM. Nursing care systematization: perceptions and knowledge of the Brazilian nursing. Rev Bras Enferm. 2019;72(6):1547-53. doi: http://dx.doi.org/10.1590/0034-7167-2018-0606

21. Silva CR, Lima EFA, Furieri LB, Caniçali Primo C, Fioresi M. Nurses' attitudes toward the nursing process. Rev Pesq Cuid Fund Online. 2018;10(4):1111-17. doi: http://dx.doi.org/10.9789/2175-5361.2018.v10i4.1111-1117

22. Trindade LR, Silveira A, Ferreira AM, Ferreira GL. Compreensão do processo de enfermagem por enfermeiros de um hospital geral do sul do Brasil. Rev Enferm UFSM. 2015;5(2):267-77. doi: http://dx.doi.org/10.5902/2179769215923

23. Silva RS, Almeida ARLP, Oliveira FA, Oliveira AS, Sampaio MRFB, Paixão GPN. Sistematização da assistência de enfermagem na perspectiva da equipe. Enferm Foco. 2016;7(2):32-6. doi: https://doi.org/10.21675/2357-707X.2016.v7.n2.803

24. Benedet SA, Padilha MI, Gelbke FL, Bellaguarda MLR. The model professionalism in the implementation of the Nursing Process (19792004). Rev Bras Enferm. 2018;71(4):1907-14. doi: http://dx.doi.org/10.1590/0034-7167-2017-0226

25. Marinelli NP, Silva ARA, Silva DNO. Sistematização da Assistência de Enfermagem: desafios para a implantação. Rev Enferm Contemp. 2015;4(2):254-63. doi: http://dx.doi.org/10.17267/2317-3378rec.v4i2.523

26. Trindade LR, Ferreira AM, Silveira A, Rocha EN. Processo de enfermagem: desafios e estratégias para sua implementação sob a ótica de enfermeiros. Rev Saúde (Santa Maria). 2016;42(1):75-82. doi: http://dx.doi.org/10.5902/2236583419805

27. Corrêa MSM, Feliciano KVO, Pedrosa EN, Souza AI. Acolhimento no cuidado à saúde da mulher no puerpério. Cad Saúde Pública. 2017;33(3):e00136215. doi: http://dx.doi.org/10.1590/0102-311x00136215

28. Arce VAR, Sousa MF. Integralidade do cuidado: representações sociais das equipes de Saúde da Família do Distrito Federal. Saúde Soc. 2013;22(1):109-23. doi: http://dx.doi.org/10.1590/S0104-12902013000100011

Financial support:

Conselho Nacional de Desenvolvimento Científico e Tecnológico (CNPq).

Programa Institucional de Bolsas de Iniciação Científica. 